\title{
Development of Logistics in Electronic Commerce
}

\author{
Shiying Fang,Wanwan Zhang,Bin Huang \\ School of Media Studies\&Humanities \\ Zhejiang University City College \\ Hangzhou, 310015, China \\ E-mail: 172740891@qq.com
}

\begin{abstract}
In order to improve the logistics informationization, solve the logistics transportation cost is high, the infrastructure issues such as compatibility. Should construct logistics electronic business, build up the modern information technology, automation technology and advanced management thoughts on the basis of integrated logistics operation mode. Examples show that the electronic commerce to logistics brings the opportunity and challenge, and logistics e-commerce change is better able to promote logistics and electronic business also two-way development.
\end{abstract}

\section{Keywords- Logistics; E-commerce; Informatization;}

*Shiying Fang is the first author; Wanwan Zhang is the correspondence author; Bin Huang is the instructor;

With the rapid development of e-commerce, growing number of people begin to pay attention to China's logistics issues_ - e-commerce bring enormous opportunities for the logistics industry while also brought great challenges. Ecommerce and logistics industry are closely linked, interact with each other.

\section{OPPORTUNITIES AND CHALLENGES OF E- COMMERCE TO THE LOGISTICS INDUSTRY}

Bachelors Day is the feast of the e-commerce industry in China while e-commerce sites like Dingdong and Dingdong take sales promotion such as big discounts Free shipping service and etc. Such big promotion becomes breakthroughs of the e-commerce industry. According to the data, Tmall, website of Chinese e-commerce enterprise Alibaba, has a trading volume exceeded one hundred million yuan in 8 minutes, as well a record volume of single day trade 33.6 million yuan that day. Tmall orders reached more than 2200 million, which shows unlimited opportunities to China's logistics industry.

Recent years, with the highly developed e-commerce industry, people are more eager to take online shopping activities, encouraging physical sellers moved to the Internet. The logistics, contacting between buyers and sellers, began to play a role in the benefits of both sides. Express business income came to 48.9 billion yuan, online shopping business takes more than $38 \%$ in amount of money, $60 \%$ in the quantity, in the first half of 2012 according to a statistic. In June 2012, the express business had revenue of 8.55 billion yuan, a year-on-year growth of $39.5 \%$ (Please refer to Figure.1)

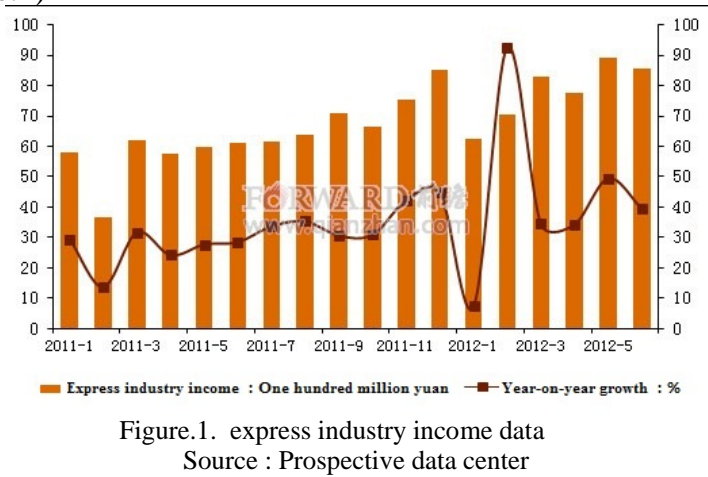

In the first half of 2012, the express business had revenue of 468.2 billion yuan, a year-on-year growth of $39.7 \%$, including city express $45.2 m i l l i o n(59.6 \%$ increasing),off-site business 281.1 billion yuan(44.9\% increasing),international business 99.2 billion yuan (11.8\% increasing). The Chinese top 5 express companies take the advantages of online shopping becoming stronger, among the quantity of day's express ,STO Express takes four million, YTO Express 300 million, ZTO Express 200 million, Yunda Express 200 million, Huitong Express 60 million. It can be said that the development of e-commerce takes logistics industry to an unprecedented stage.

The contradiction between developed e-commerce and poor logistics environment occurs to China. The requirement of e-commerce express service is increasing at the rate of $100 \%$ is bared be met by express companies increasing at a lower rate of $30 \%$ to $50 \%$. Logistics gradually become the bottleneck of the e-commerce industry. As the Bachelors Day's sale mentioned before shows, the great demand of 22 million express is a huge benefit to logistics industry, while also needs more space than existing warehouse. Complaint for the longer delivery time came due to the shorts of hands, which leads to overstock of express. It troubles online shopping consumers that errors occur in referring to logistics information. The delay of delivery brings huge numbers of issues such as the lose of money due to the characters of payment platform which have a influence to both e-commerce and express companies. For the loose cooperative relationship between e-commerce 
businesses and express companies, the critical basic information, such as the weight, volume, etc are unknown while billions of express are sent everyday, which results in the information lag between different levels cells of express, leading to the unreasonable setting in staff and vehicles. All above this series of problems restricts the development of China's logistics, affecting the development of e-commerce.

Overall, the opportunities and challenges brought about by the e-commerce for the logistics industry is huge. Ecommerce and logistics affect each other, simultaneously grow with cooperation.

\section{PROBleMS OF LOGISTICS AND E-COMMERCE AND THE NECESSITY OF CONSTRUCTION OF INTEGRATED LOGISTICS OPERATION MODE}

The informatization of logistics is the inevitable requirement of e-commerce. High proportion of logistics costs takes a big percentage of GDP, declining slowly. The costs to GDP ratio is basically maintained at a level of about $20 \%$, comparing with the logistics costs worldwide, having a difference of about 8 to 10 percents. It clearly reflects the level of China's logistics efficiency is still low. At present, there are still many problems in China's logistics industy.

\section{A. Low logistics technology and equipment level}

China's e-commerce logistics enterprises has a low level in equipment, information technology, integrated management, logistics operations and technology. Uneven level of logistics technology and equipment, reflecting in the states of manual and industrial sorting and carrying are existing at the same time, is badly in need to improve.

\section{B. Lack of awareness of Electronic Commercialized Logistics}

China's logistics management system and mechanism is still very immature, and there are many obstacles. For example, the development of the logistics industry involves infrastructure, logistics and technical equipment, industrial policy, taxation, customs, transport standards, which has a relative to different department of government and enterprise whose attitudes are lack. All these above restrict the development of Electronic Commercialized Logistics.

\section{Lack of professinal personnel}

Logistics talent shortage in China is an indisputable fact for the scale of logistics major in colleges are small, which bring to the lack of talents who have a full grasp of logistic and economy knowledge. Most logistics enterprises lack of scientific operations and management decision-making process due to the low quality of logistics practitioners, leading to the high cost and management confusion.

\section{Lack of the Building of Standard}

The construction of the standardization of China's logistics system is far from perfect, and the formulation and revision of the standard of logistics information not keeping up with the needs of economic development. China Logistics Standardization lag mainly performed in the lack of relevant standards and regulations, and in the implementation of standards.

Due to the late start in some places, the formulation and revision of standard has not been included in the government work schedule; sense of participation in standardization activities is inactive; logistics standardization work coordination mechanism has not really formed; management system and personnel level as well as many aspects there are obvious shortcomings. The lag of standardization of logistics information severely restricted to the highly developed logistics informatization. Moreover, It is a long-standing lack of domestic, international and ASEAN logistics standard consulting and services for enterprise that has hampered the healthy and rapid development of the logistics industry.

In addition, there are still some problems in China's logistics industry, as high transport costs, poor infrastructure compatibility issues. These factors are checks and balances with the development of the logistics industry. Therefore, we need to construct the logistics of e-commerce, the established modern information technology, automation technology and advanced management ideas based on integrated logistics mode of operation to promote the development of the logistics industry.

Electronic commercialized logistics is to provide information on the Internet, including freight, air transport, land transport, shipping information, as well as the logistics industry information and logistics knowledge of laws and regulations, etc. Enterprise Library of logistics industry is also to be available which shows great convenient to the mail sender to select and cooperate. The building of electronic commercialized logistics not only help to reduce the human resource cost, improve work efficiency, but also helps to make full use of information resources from suppliers and customers.

In addition, the infrastructure is well-developed: road mileage of 1.6 million $\mathrm{km}$, of which over $15,000 \mathrm{~km}$ is highway, ranking third in the world; rail capacity ranks first in Asia; water transport, ports throughput capacity has greatly improved up to the world's fifth; civil aviation has made substantial progress, a new expansion of a number of airports and feeder, additional international routes, airlift capacity and quality has been greatly improved. In addition, third-party logistics industry have been rising, a good development trend. These provide a good foundation for the logistics and e-commerce.

\section{ADVICES ON ELECTRONIC COMMERCIALIZED LOGISTICS}

\section{E. Base Customer-centric, Integrated Logistics Services}

E-commerce Logistics is to achieve the philosophy of service assurance "customer-centric". The build of the ecommerce logistics need to meet the consumer pleasant, that is, the timely receipt of goods, which comes from comprehensive logistics services. Now, the majority of logistics enterprises evolved from the traditional materials circulation enterprises, whose majority services remains in the storage, transportation, handling. Few logistics 
companies are able to provide comprehensive logistics services.

Thus, modern logistics companies need to establish a modern logistics services with high efficiency and low cost requirements, consistent with e-commerce. Improvement in terms of information collection, processing, handling, using as well as logistics co-ordination of planning and refined management capabilities should take place. Only in this way, good relationship between logistics and consumers will be formed, as well as good relationship of cooperation and electricity supplier.

\section{F. Informatization Logistics Based on the Internet}

With the fierce competition between logistics companies, logistics enterprises began to focus on the Internet- - the most potential community, Investing in the construction of logistics websites, integrating logistics industry resources, to establish the logistics industry trading platform to win more customers. The term of logistics network contains two meanings: First, the logistics system of computer communication networks, including logistics distribution center and suppliers, as well as clients, contacting through computer network. The second is a network of organizations, the so-called intranet. With logistics network, the user can find the logistics network in the integrated logistics based on his location or refer to some information.

Meaning of development of modern logistics informatization

- Help to establish a new customer relationship. Enterprise form a new relationship between upstream suppliers and downstream customers with the internet technology.

- A new way to know the market demand, and accelerate the speed of reaction. The development of information technology can make global multinational companies extend business to anywhere in the world. The development of information technology leads to information efficient use, managers can use manage logistics, simulation is also available in decision-making results.

- Help to improve the channel efficiency. Via the Internet ordering and inventory systems, enterprises can have a master about the retailer's merchandise sales information, and to improve the efficiency of marketing channels, improve customer satisfaction.

- Help build a value chain between enterprises, changing the traditional supply chain. IT can take advantage of each company's core capabilities and industry common practice to build inter-enterprise value chain through fuzzy distinction between products and services, and to change the composition of the traditional supply chain.

The rapid development of e-commerce will change the competitive environment of enterprises. Establish and maintain the competitive advantage, enterprise should use the Internet to logistics activities and for proper management. It is the twenty-first Century the logistics development trend that carrying out logistics activity logistics management and revolution through the Internet.
Revision laws and regulations, improve the understanding of electronic logistics

The development of modern logistics is still in its infancy, although the relevant state ministries and commissions introduced some relevant policies and regulations, but is still not perfect. If not promptly improve relevant regulations, logistics of electronic commerce will miss a great opportunity. Logistics is a service industry, if the policy did not have a unified standard, it will seriously hinder the industry development.

To change this situation, first we should improve all aspects, especially the government functional departments and related enterprises to the electronic logistics knowledge, and gradually establish logistics industry associations, to implement the logistics market needs of industry selfregulation. While promoting the government from the policy support, the logistics industry associations of the functions, powers, functions, and relevant government departments, communication links to specific legal provisions. Through the compilation of revision of our existing content sheds administrative regulations; combing logistics policies and regulations of the intrinsic logical, straighten each specification, regulations to undertake and progressive relationship between legal norms, improve logistics level effect, strengthen its maneuverability. Break, rectify and restrict area block and industry monopoly acts of unfair competition, and create a fair, just, open logistics market environment. Rigorous examination of qualification of admittance of market of logistics enterprises, so that various types of logistics enterprises in a fair, efficient market competition in the survival of the fittest.

\section{G. Strengthening electronic commerce logistics professional training}

What Electronic commerce logistics needs is the talented person with compound talents, who need both to understand e-commerce, but also understand the logistics, both management and technology. At present our country has this kind of talent shortage, which needs government, enterprise, and schools joint efforts to make up for.

First of all, the government should give full play to guide regulation, formulate the related policy, laws and regulations, encourage, support of colleges, and scientific research institutions in the logistics informatization to carry out education and training, but also in terms of money to help these education and training institutions, teachers increase their input.

Second, the school should establish and perfect the teaching plan, set up the logistics profession, establish logistics electronic commerce research and study abroad system way to develop modern logistics talents. Strengthen the teacher strength, and actively introducing talent and expert guidance, training students' ability to adapt. At the same time construction of logistics training base, combining students' technical and management double aspects of learning, to combine theory with practice effects to enhance logistics electronic commerce professional training, in order to better to face the modern logistics development by leaps and bounds. 
The last is that the enterprise should build its own personnel training and development system, paying more attention to internal mining and cultivation of talents, fully aware of the value of the enterprise development. It can not only make the enterprise logistics informatization respects go ahead of its competitors, but also can effectively ease the logistics enterprises face in the talent bottleneck.

Electronic commerce logistics use information resources reorganization of business processes. The development of China's e-commerce logistics is very necessary and required. The future, the logistics of our country will inevitably toward informatization, automation, intelligent direction, and walk in the globalization.

\section{REFERENCES}

[1] YL.Hu, HJ.Ma, YW.Wang "Logistics management in electronic commerce” NO 2011 PP 34--45

[2] SQ.Fan, Q.Wang, H.Wang, C.He “ Electronic commerce” Spet 2010 PP67--78

[3] HY Xie。HT.Xin “ Logistics of electronic commerce” Mar 2009PP $132--150$

[4] H.Zhou, XQ.Luo, XY.Yi, HJ.X, ,D.Yan” Logistics of electronic commerce"K. Elissa, "Title of paper if known," unpublished Dec 2009 PP 143--190 